\title{
Study on Parasitic Load in Local Goats Reared in Three Different Systems of Rearing
}

\section{Mahadev Lamani ${ }^{1}$, SB Prasanna ${ }^{2 *}$, Mahadevappa D Gouri ${ }^{3}$, Suma $\mathbf{N}^{4}$ and Shankarappa Bhajantri ${ }^{3}$}

${ }^{1}$ Veterinary Officer, Government of Karnataka, India

${ }^{2}$ Department of LPM, Veterinary College, Hebbal, Bangalore, India

${ }^{3}$ Department of LFC, Veterinary College, Hebbal, Bangalore, India

${ }^{4}$ Department of Animal Nutrition, Veterinary College, Hebbal, Bangalore, India

*Corresponding Author: SB Prasanna, Department of LPM, Veterinary College, Hebbal, Bangalore, India.
Received: September 28, 2020

Published: December 10, 2020

(C) All rights are reserved by SB Prasanna., et

al.

\section{Abstract}

An experiment to study the effect of three systems of rearing on the parasitic load and welfare of growing goat kids were studied. The 3 months study was conducted on local osmanabadi crossbred goats at Niharika Sheep and Goat Farm, Sira, Tumkur district, Karnataka, India. Thirty weaned local goat kids (3 months) were randomly allocated into three treatment groups with ten kids in each viz., $\mathrm{T}_{1}$ (Intensive-in housed and fed all time), $\mathrm{T}_{2}$ (Semi intensive- browse for 5 - 6 hours during day time, housed and fed rest of time) and $\mathrm{T}_{3}$ (Extensive rearing- browse throughout the day 6 - 8 hours and no feed supplementation). The animals in $\mathrm{T}_{1}$ group were confined to the shed both during day and night.

The average parasitic load at the beginning of the trial was $180 \pm 38.15,205 \pm 36.86$ and $185 \pm 33.37$ in $\mathrm{T}_{1}, \mathrm{~T}_{2}$ and $\mathrm{T}_{3}$, respectively. At the end of experimental trial, parasitic load was $1320 \pm 35.12,1985 \pm 75.3$ and $2235 \pm 91.91$ eggs per gram in $\mathrm{T}_{1}, \mathrm{~T}_{2}$ and $\mathrm{T}_{3}$ respectively. This study indicates to design a suitable deworming program to control helminths more often in extensive system while for protozoans like coccidiosis in intensive system of rearing.

Keywords: Goat; Intensive; Extensive; Semi Intensive; Helminth; Protozoans

\section{Introduction}

Goats are one of the important small ruminants which have been domesticated by man since time immemorial. Sheep and goat contribute to the livelihoods of millions of rural poor in most of the developing countries of the Asia and Africa, where 95\% of the world's sheep and goat population is concentrated. Their production has witnessed excellent growth over the years. Hence Small farmers and landless agricultural labourers are increasingly relying on sheep and goats for meeting their cash requirements [1].

Rising world population and economic development have led to global demand for meat, milk and other animal products that are increasing dramatically. Parasites are major constraints to commu- nal goat production and safe utilization of goat products. The impact of parasites manifested as weight loss or reduced gains. They have a heavy impact on kids because of the poor immunity status of these young animals leading to an increased susceptibility and high kid mortality that diminishes the benefits of the high reproductive performance of does [2].

Internal parasite infestations of herds can cause major health issues, which have a major effect on the animal's performance and cause great economic loss to the producer. In fact, most of the economic losses caused by internal parasites are actually not due to mortality but production loss [3]. Controlling parasitic diseases in goats, in particular helminth infections, could rapidly improve pro- 
ductivity and resource utilization. Hence it is essential to study the systems of rearing of small ruminants and their influence on the productive performance in relation to parasitic load.

\section{Materials and Methods}

The experiment was carried out at Niharika Sheep and Goat Farm located at Sira $\left(13.7448^{\circ} \mathrm{N}, 76.8990^{\circ}\right.$ E) Tumakur District, Karnataka, India. Thirty weaned Osmanabadi crossbred Goat kids aged 3 to 4 months were purchased from local goat market of Sira. The goats were selected based on comparable body weights and randomly allocated into three treatment groups with ten kids in each group ( 5 male and 5 females). The present study was carried out for a period of three months (90 days) during January 2018 to April 2018 to assess the impact of different rearing systems on growth performance of weaned kids.

Three groups comprised of $\mathrm{T}_{1}$ (Intensive system) group animals which were stall fed and confined to the shed both during day and night. The kids were fed with roughage and concentrates as per the specifications [4]. Clean and potable drinking water was made available round the clock. The $\mathrm{T}_{2}$ (Semi Intensive system) group animals were let out for grazing for a period of 6 hours and provided with supplementary feeding on return and in $\mathrm{T}_{3}$ (Extensive system) group, animals were exclusively maintained on grazing for 6 - 8 hours per day without any extra supplementation and were housed in shed for rest of day. The feeding schedule of the experimental animals has been presented in the table 1 .

\begin{tabular}{|c|c|c|c|}
\hline $\begin{array}{l}\text { Treat- } \\
\text { ment }\end{array}$ & $\begin{array}{l}\text { No of } \\
\text { Ani- } \\
\text { mals }\end{array}$ & $\begin{array}{c}\text { Average } \\
\text { body } \\
\text { weight (Kg) }\end{array}$ & Management \\
\hline $\mathrm{T} 1$ & 10 & 11.05 & $\begin{array}{c}\text { 215g Concentrate }+100 \mathrm{~g} \\
\text { Sesbania }+100 \mathrm{~g} \\
\text { Ground nut hay }+ \text { ad libitum } \\
\text { Ragi straw }\end{array}$ \\
\hline $\mathrm{T} 2$ & 10 & 11.05 & $\begin{array}{c}\text { 100g Concentrate }+50 \mathrm{~g} \text { Sesba- } \\
\text { nia }+50 \mathrm{~g} \\
\text { Ground nut hay }+ \text { ad libitum } \\
\text { Ragi straw }+6 \\
\text { hours of browsing }\end{array}$ \\
\hline $\mathrm{T} 3$ & 10 & 11.14 & $\begin{array}{c}6 \text { - } 8 \text { hours of daily browsing } \\
\text { only }\end{array}$ \\
\hline
\end{tabular}

Table 1: Feeding schedule of experimental kids.

\section{Housing management}

Since the experiment was carried out in field condition, simple Semi open shed was constructed using locally available materials.
One week prior to arrival of the animals the experimental feeders, waterers and floor were thoroughly disinfected. The goats were housed on mud floor with ample ventilation in and around animal house roofed under coconut leaves and plastic sheet. The standard management practices in animal house along with the traditional management practices of goat rearing outside the house were followed for all groups similarly. Uniform floor space of $1 \mathrm{~m}^{2}$ was provided to all the groups throughout the experimental period. The housing system has been shown in the plate (Figure 1 and 2).

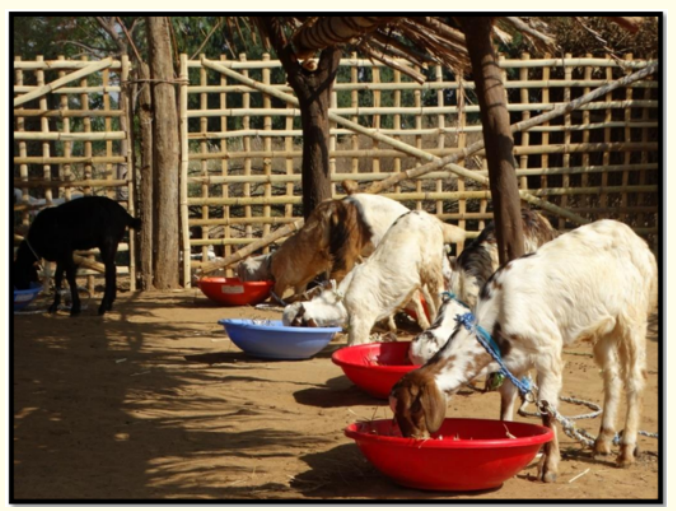

Figure 1: Experimental animals under intensive system of management.

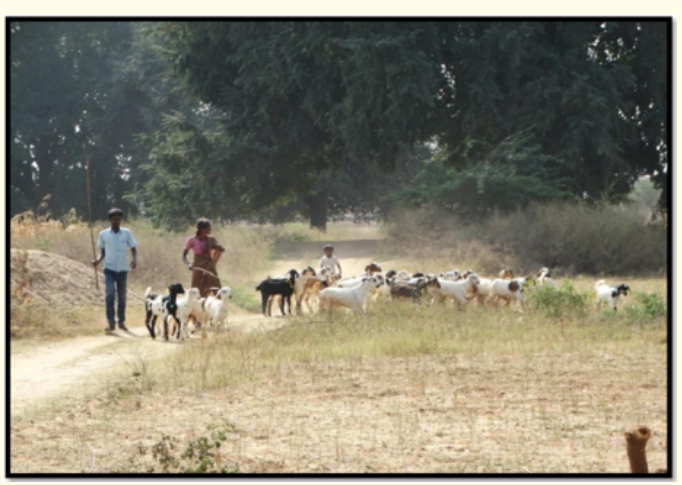

Figure 2: Experimental animals under semi intensive and extensive system of management grazing on nearby field.

\section{Study of parasitic load}

Fifteen days prior to start of the experimental trial, all the kids in treatment group $\mathrm{T}_{1}, \mathrm{~T}_{2}$ and $\mathrm{T}_{3}$ were dewormed with Fenbendazole and Praziquantel combination as per the prescribed dosage. Faecal samples were collected directly from the rectum and sub- 
jected to qualitative and quantitative analysis to access the parasitic load by modified McMaster's technique [5] and results were statistically analyzed.

\section{Results and Discussion}

The average parasitic load in kids reared under three different systems i.e. treatments $\mathrm{T}_{1}$ and $\mathrm{T}_{2}$ and $\mathrm{T}_{3}$ is presented in table 2 and figure 3. The average initial and final Parasitic loads were $180 \pm$ 38.15 and $1320 \pm 35.12$ in $\mathrm{T}_{1}$ group, $205 \pm 36.86$ and $1985 \pm 75.3$ in $\mathrm{T}_{2}$ group, $185 \pm 33.37$ and $2235 \pm 91.91 \mathrm{EPG}$ (Eggs Per Gram) in $\mathrm{T}_{3}$ groups respectively. There was no significant difference in mean parasitic load between treatments $\mathrm{T}_{1}, \mathrm{~T}_{2}$ and $\mathrm{T}_{3}$ at day one but highly significant $(\mathrm{P}<0.01)$ differences among treatment groups $\mathrm{T}_{1} \mathrm{Vs}$ $\mathrm{T}_{2}$ and $\mathrm{T}_{1} \mathrm{Vs}_{\mathrm{T}} \mathrm{T}_{3}$ were observed at the end of 90 days of experimental trial suggesting low parasitic load in Intensive group.

\begin{tabular}{|c|c|c|c|c|c|}
\hline $\begin{array}{c}\text { Sl. } \\
\text { No. }\end{array}$ & $\begin{array}{c}\text { Period } \\
\text { (days) }\end{array}$ & $\begin{array}{c}\text { T1 (In- } \\
\text { tensive } \\
\text { system) }\end{array}$ & $\begin{array}{c}\text { T2 (Semi } \\
\text { intensive } \\
\text { system) }\end{array}$ & $\begin{array}{c}\text { T3 (Ex- } \\
\text { tensive } \\
\text { system) }\end{array}$ & $\begin{array}{c}\text { P } \\
\text { Value }\end{array}$ \\
\hline 1 & 0 & $180 \pm 38.15$ & $205 \pm$ & $185 \pm$ & 0.8755 \\
& & 36.86 & 33.37 & \\
\hline 2 & 30 & $555 \pm$ & $885 \pm 85^{\mathrm{b}}$ & $1030 \pm$ & 0.0005 \\
& & $64.31^{\mathrm{a}}$ & & $76.45^{\mathrm{b}}$ & \\
\hline 3 & 60 & $1035 \pm$ & $1490 \pm$ & $1745 \pm$ & 0.0001 \\
& & $48.33^{\mathrm{a}}$ & $108.7^{\mathrm{b}}$ & $85.13^{\mathrm{b}}$ & \\
\hline 4 & 90 & $1320 \pm$ & $1985 \pm$ & $2235 \pm$ & 0.0001 \\
& & $35.12^{\mathrm{a}}$ & $75.3^{\mathrm{b}}$ & $91.9^{\mathrm{b}}$ & \\
\hline
\end{tabular}

Table 2: Average parasitic load (EPG) of Faecal sample of kids during different days of experimental period.

Note: Means in a row with different superscripts differ significantly with each treatment group (a, b, c-superscript).

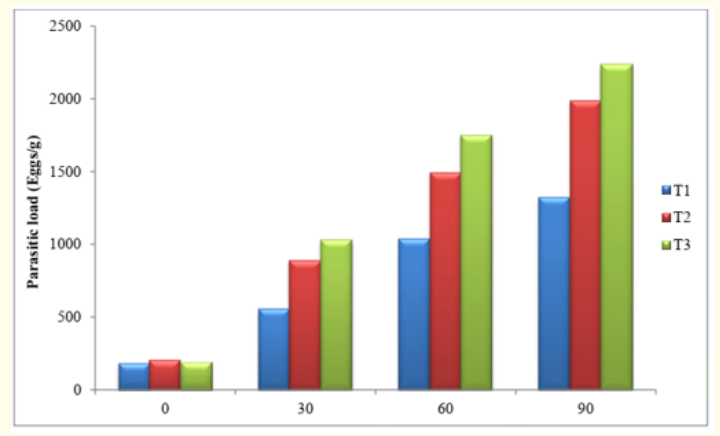

Figure 3: Average parasitic load (EPG) in kids during different days of experimental trial.

\section{Types of internal parasites}

Different species of parasites (per cent) in the faecal samples of kids reared under Intensive $\left(\mathrm{T}_{1}\right)$, Semi intensive $\left(\mathrm{T}_{2}\right)$ and Extensive $\left(\mathrm{T}_{3}\right)$ group are presented in table 3 and figure 4 . The proportions of Strongyle and Moniezia were significantly higher in $\mathrm{T}_{2}$ and $\mathrm{T}_{3}$ than $\mathrm{T}_{1}$ group. The Trichuris eggs and Oocysts of Eimeria was higher in $\mathrm{T}_{1}$ group but the values were non-significant.

\begin{tabular}{|l|c|c|c|c|}
\hline Parasitic egg & T1 & T2 & T3 & P Value \\
\hline Strongyle eggs & $44.50^{\mathrm{a}}$ & $52.10^{\mathrm{b}}$ & $57.70^{\mathrm{b}}$ & 0.0001 \\
\hline Trichuris eggs & 22.50 & 15.70 & 17.70 & 0.2382 \\
\hline Moniezia eggs & $10.70^{\mathrm{a}}$ & $18.80^{\mathrm{b}}$ & $15.00^{\mathrm{b}}$ & 0.0009 \\
\hline Oocysts of Eimeria & 22.30 & 13.40 & 9.62 & 0.2878 \\
\hline
\end{tabular}

Table 3: Different species of parasites (per cent) in the faecal samples of kids during 91 days of experimental period.

Note: Means in a row with different superscripts differ significantly with each treatment group (a, b, c -superscript).

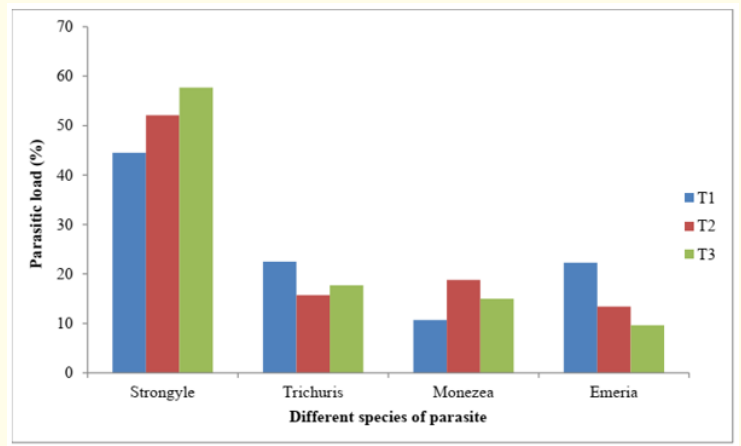

Figure 4: Different species of parasites (per cent) in the faecal samples of kids during entire experimental period.

Initial parasitic load was almost similar on day one of the Experimental period in all treatment groups and the parasitic load (Eggs per gram) significantly increased in $\mathrm{T}_{2}$ and $\mathrm{T}_{3}$ compared to $\mathrm{T}_{1}$ group could me mainly due letting out the $\mathrm{T}_{2}$ and $\mathrm{T}_{3}$ animals for grazing where they might have come in contact with intermediate hosts or larval stages of endoparasites. In this study mainly three types of helminth ova (Strongyles, Trichuris and Moniezia) and one protozoan (Oocysts of Eimeria) species was identified in different proportions in different treatment groups.

The proportion of Strongyle eggs were predominant in kids from semi intensive (52.1\%) and extensive management $(57.7 \%)$ 
compared to Intensive system of management (44.5). $\mathrm{T}_{2}$ and $\mathrm{T}_{3}$ group animals were allowed to graze freely in the fields where they might have come in contact with open water bodies like ponds, cannels, marshy land and exposed to helminth infestation.

In contrast, the proportion of Moniezia eggs was more in the faecal samples of the kids reared under Semi intensive group (18.8\%) and proportion of Oocysts of Eimeria was more in intensive system $(22.3 \%)$. This could be due to the fact that Eimeria are shed in faecal material and the possibilities of kids coming in contact with these parasites in increased frequencies are much higher in the kids under intensive management compared to those under semi intensive and extensive system of management.

Results of the present experiment were in close agreement with [6] who recorded prevalence of helminths and protozoa significantly higher in extensive system (86.1\%) followed by semi intensive $(76.3 \%)$ and intensive system $(57.5 \%)$ and stated goats reared under extensive and semi intensive systems were 4.6 and 2.4 times more susceptible to helminth infection than those of intensive system. They also observed that goats under extensive rearing system were 1.9 times more susceptible to helminth infection than those of semi intensive system. Pandit BA., et al. [7] had reported higher nematode infections in the field managed sheep (88.4\%) than the farm managed sheep (75.9\%). Higher parasitic load in extensive and semi intensive systems were also reported by several authors [8-11].

The dynamics of faecal egg count is variable according to different seasons, physiological status, breed, age, managemental practices and different geographical regions. Species wise prevalence of present study was in partial agreement with several authors [1218].

There are several strategies to control the parasitic infestation whereby [19], suggested totally housing the animals and feed them with 'cut and carry' uncontaminated grasses. As an alternative to drugs, the option of feeding small ruminants with herbal neem leaves (Azadirachta indica) have been reported to give promising results in small ruminant worm control [20].

The present study suggested rearing system has great impact on the prevalence of parasites and their load and regular deworming and health management is essential to enhance the productivity. As seen from this study the parasites are prevalent in all three systems of rearing, the level of loads is significantly less in confined housed goats. Further in this study coccidiosis infestation is observed to be more in $\mathrm{T}_{1}$ (under Intensive system of rearing) group kids housed indoor whereas helminths in general are observed more in outdoor reared goats ( $\mathrm{T}_{2}$ and $\mathrm{T}_{3}$ groups). Thus, this study envisages that a suitable deworming program can be designed to control the helminths which occurred more often in extensive system while for protozoans like coccidiosis that occurred more often in intensive system of rearing.

\section{Conclusion}

It can be inferred that management of goats in different rearing systems has an important role in control of external or internal parasites. Particularly deworming should be aimed primarily to control protozoan parasites in confined intensive rearing system while aiming to control both the protozoans and helminth parasites in semi intensive and extensive rearing systems.

\section{Bibliography}

1. Shiva Kumara C., et al. "Small Ruminant Production in Karnataka State of India- an Overview". European Journal of Zoological Research 5.1 (2017): 28-35.

2. Sebei PJ., et al. "Factors influencing weaning percentages of indigenous goats on communal grazing". South African Journal of Animal Science 34 (2004): 130-133.

3. Waller PJ. "Management and control of nematode parasites of small ruminants in the face of total anthelmintic failure". Tropical Biomedicine 21 (2004): 7-13.

4. Indian Council of Agriculture Research "Nutrient Requirements of Animals-sheep, goat and rabbit". ICAR, NIANP, New Delhi, $2^{\text {nd }}$ Edition (2013): 52.

5. Coles GC., et al. "The detection of anthelmintic resistance in nematodes of veterinary importance". World Association for the Advancement of Veterinary Parasitology (W.A.A.V.P) Veterinary Parasitology 44 (1992): 35-44.

6. Rabbi AK., et al. "Does feeding system influence parasitism in Black Bengal goats in Bangladesh". Progressive Agriculture 22.1-2 (2011):85-95.

7. Pandit BA., et al. "Survey of gastrointestinal nematodes in sheep of Kashmir valley". The Indian Journal of Small Ruminants 9 (2003): 39-42.

8. Jagatheesan PNR., et al. "Parasitic load of Madras Red sheep in different systems of management". The Indian Journal of Small Ruminants 9(2003): 176-180. 
9. Sudharshan V., et al. "Influence of method of rearing on the parasitic load in Mandya sheep". IJAR - Indian Journal of Applied Research 6.10 (2016): 553-555.

10. Dinesh Kumar Sharma and Ajoy Mandal." Factors affecting gastrointestinal parasite infections in goats in semi-arid rural ecosystems in India". Veterinary Science Development 3.1 (2013): 24-27.

11. Zvinorova PI., et al. "Prevalence and risk factors of gastrointestinal parasitic infections in goats in low-input low-output farming systems in Zimbabwe". Small Ruminant Research 143 (2016): 75-83.

12. Bashir Ahmad Lone., et al. "A Survey of Gastrointestinal Helminth Parasites of Slaughtered Sheep and Goats in Ganderbal, Kashmir". Global Veterinaria 8.4 (2012): 338-341.

13. Mishra S., et al. "Prevalence of gastrointestinal parasites in goats". The Indian Veterinary Journal 87 (2010): 1033-1034.

14. Patel MD., et al. "Prevalence of gastro intestinal parasitism in goats maintained under semi intensive and field management systems". The Indian Journal of Veterinary Medicine 21.2 (2001): 99-101.

15. Soliman MFM and Zalat SM. "Prevalence and intensity of Nematodirus sp. and Eimeria sp. infections in the domestic goats of St. Katherine's Protectorate (Sinai, Egypt): relations with some ecological and biological factors". The Egyptian Journal of Biology 5 (2003): 78-85.

16. Velusamy R., et al. "Prevalence of intestinal and haemoprotozoan parasites of small ruminants in Tamil Nadu, India”. Veterinary World 8.10 (2015): 1205-1209.

17. Satish AC., et al. "Prevalence of Gastrointestinal Parasites in Small Ruminants in and around Chennai, Tamil Nadu". Veterinary World 95.02 (2018): 78-79.

18. Singh V., et al. "Prevalence of gastrointestinal parasites in sheep and goats in and around Mathura, India". Jurnal Veterinar Malaysia 6.5 (2018): 260-262.

19. Azlina AA., et al. "Anthelmintic resistance of selected goat farms in Terengganu". Jurnal Veterinar Malaysia 23.1 (2011): 19-23.

20. Chandrawathani P., et al. "Evolution of high-level, multiple anthelmintic resistance on a sheep farm in Malaysia". Tropical Animal Health and Production 35 (2003): 17-25.

\section{Assets from publication with us}

- Prompt Acknowledgement after receiving the article

- Thorough Double blinded peer review

- Rapid Publication

- Issue of Publication Certificate

- High visibility of your Published work

Website: www.actascientific.com/

Submit Article: www.actascientific.com/submission.php

Email us: editor@actascientific.com

Contact us: +919182824667 